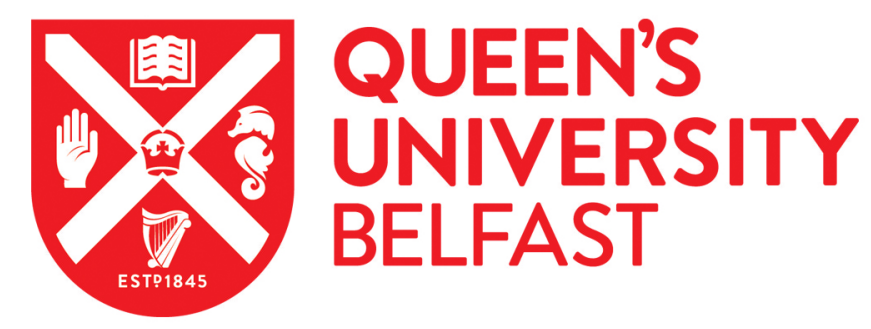

\title{
Genetic evidence supports recolonisation by Mya arenaria of western Europe from North America
}

Cross, M. E., Bradley, C. R., Cross, T. F., Culloty, S., Lynch, S., McGinnity, P., O'Riordan, R. M., Vartia, S., \& Prodöhl, P. A. (2016). Genetic evidence supports recolonisation by Mya arenaria of western Europe from North America. Marine Ecology: Progress Series, 549, 99-112. https://doi.org/10.3354/meps 11672

Published in:

Marine Ecology: Progress Series

Document Version:

Peer reviewed version

Queen's University Belfast - Research Portal:

Link to publication record in Queen's University Belfast Research Portal

Publisher rights

(C) 2016 Inter-Research.

\section{General rights}

Copyright for the publications made accessible via the Queen's University Belfast Research Portal is retained by the author(s) and / or other copyright owners and it is a condition of accessing these publications that users recognise and abide by the legal requirements associated with these rights.

Take down policy

The Research Portal is Queen's institutional repository that provides access to Queen's research output. Every effort has been made to ensure that content in the Research Portal does not infringe any person's rights, or applicable UK laws. If you discover content in the Research Portal that you believe breaches copyright or violates any law, please contact openaccess@qub.ac.uk. 


\section{Accepted Manuscript}

2

3 Genetic evidence supports recolonisation by Mya arenaria (L.) of western Europe from

4 North America

5

6 M. E. Cross, C. R. Bradley, T. F. Cross, S. Culloty, S. Lynch, P. McGinnity, R. M.

7 O'Riordan, S. Vartia and P. A. Prodöhl

8

9 Published in MEPS Vol. 549:99-112 (2016).

10 DOI:10.3354/meps 11672

11 Accepted date: 25 February 2016

12 Online publication date: May 10, 2016

13 Print ISSN: 0171-8630; Online ISSN: 1616-1599

14 

North America.

1. Aquaculture and Fisheries Development Centre, School of Biological, Earth and Environmental Sciences, University College Cork, Ireland. Biology Centre, 97 Lisburn Road Belfast BT9 7BL, Northern Ireland - UK.

3. Carna Research Station, Ryan Institute, National University of Ireland, Galway, Carna, Connemara, Co. Galway, Ireland.

*To whom correspondence should be addressed: maud.cross@ucc.ie

Running title: Genetics of Mya arenaria.

\section{Abstract}

Mya arenaria (L.), the softshell clam, is currently widespread on the east and west coasts of North America. This bivalve also occurs on western European shores where the post Pleistocene origin of the species, whether introduced or relict, has been debated. In this study 320 M. arenaria from eight locations in Europe and North America were collected. Eightyfour clams from seven of the locations were examined for mitochondrial DNA variation by sequencing a section of the cytochrome oxidase I (COXI) gene. These were analysed together with 212 sequences, sourced from Genbank, from the same gene from 12 additional locations, chiefly from eastern North America but one site each from western North America and one from western Europe. Ten microsatellite loci were also investigated in all 320 clams. Nuclear markers showed reduced levels of variation in certain European samples. The same common $C O X I$ haplotypes and microsatellite alleles were present throughout the range of $M$. arenaria, though significant differences were identified in haplotypic and allelic composition between many samples, particularly those from the two continents, Europe and North America. These findings support the hypothesis of post Pleistocene colonisation of European shores from eastern North America (and the recorded human transfer of clams from the east to the west coast of North America in the $19^{\text {th }}$ Century). 


\section{INTRODUCTION}

Following the retreat of the glaciers at the end of the Pleistocene some 12,000 years ago, recolonisation of northern Europe, in particular for most terrestrial species, is presumed to have originated from one, two or three refugia in southern Europe i.e. Iberia, Italy and the Balkans (Hewitt 1999). In the case of shallow water and inter-tidal marine species, the situation was different in that post-glacial colonists from the south (contemporary Iberia, western North Africa and the Mediterranean) had to follow coastlines, which experienced rapid changes in sea level (Maggs et al. 2008). The fact that many marine species have pelagic larvae is thought to increase the potential for rapid colonisation (Luttikhuizen et al. 2003, Dupont et al. 2007, Arias-Perez et al. 2012), despite other factors (e.g. ocean currents, salinity and temperature levels) which can prevent gene flow. In more recent times, planktonic larvae of marine species could also be distributed anthropogenically in ballast or bilge water of ships (Briski et al. 2012, Ruiz et al. 1997) or as adults, particularly gastropod or bivalve mollusc species, which, when retained as fresh food items, can survive long sea journeys, if held in low temperature sea water.

Notwithstanding the European refugial hypothesis (see Maggs et al. 2008), certain marine mollusc species currently occupying North Atlantic coastal regions appear to have had a different route of colonisation which involved trans-oceanic movement. The edible winkle Littorina littorea (Linnaeus 1758) (Prosobranchia, Gastropoda) is thought to be one such species (Chapman 2007, Chapman et al. 2007, Chapman et al. 2008). Arguably not present on eastern North American shores after the Pleistocene glaciations (Chapman 2007, Chapman et al. 2008, Blakeslee et al. 2008, Blakeslee \& Byres, 2008), the suggestion is that it was introduced as a food source to Newfoundland, or through rock ballast to Nova Scotia (Chapman et al. 2007). It was first recorded in the latter area in 1840 (Brawley et al. 2009) and thereafter spread south (Beebee \& Rowe 2008, Harley et al. 2013). The opposite (colonisation of European shores from eastern North America (Strasser 1999)) is believed to be the case for the infaunal bivalve species, the softshell clam Mya arenaria (Linnaeus 1758), considered in the present study. Now recognised as an important member of the intertidal infaunal community in the North East Atlantic (Strasser 1999), the species occurs over a wide geographical range from Iceland, the White Sea and northern Norway to Portugal (Strasser 1999, Conde et al. 2010), including the Barents and Black Sea, with recent reports of its presence also in the Mediterranean Sea (Zaitsev \& Mamaev 1997, Weston \& Buttner 2010, 
Crocetta \& Turolla 2011). Archaeological evidence suggests that $M$. arenaria was present in this region in the late Pliocene (Strauch 1972), and that it disappeared from European shores during the Pleistocene glaciations. M. arenaria is then thought to have reappeared, postglacially, on European shores. The reintroduction may have been either natural or anthropogenic, with previous suggestions that the Vikings were responsible (MacNeil 1965, Strauch 1972, Petersen et al. 1992).

Molecular genetics, as used in the present study, provides a mechanism for testing the hypothesis of trans-Atlantic colonisation. If trans-Atlantic colonisation was exclusively or predominately the case, similar genetic composition would be expected in $M$. arenaria from the coasts of the eastern and western Atlantic. This constitutes the hypothesis explored here i.e. that colonisation of western European shores was from eastern North America. In contrast, different genetic composition would be expected in softshell clams from either side of the ocean if post-Pleistocene northern European colonisation had involved southern or peri-glacial European refugia. In this case, genetic differences would have evolved as a consequence of forces such as mutation, genetic drift and selection, while the two assemblages were separated throughout the Pleistocene.

In addition, a single or limited number of colonisation events, limited to a small number of founders, would result in substantially lower genetic variability in northern European populations. Therefore, M. arenaria occurring south of the glaciated areas in eastern North America, would be more genetically variable than those in Europe. In this way, another feature of the colonisation process can be elucidated.

Previous genetic studies of M. arenaria concentrated on eastern North American coasts and used markers such as allozymes (Levinton 1973, Morgan et al. 1978). Where European samples were included, little inter-continental variation was observed throughout the contemporary range (Lasota et al. 2004). As M. arenaria is known to be a successful coloniser within European waters (Bologa et al. 1995, Zaitsev \& Mamaev, 1997), and similar genetic composition was observed on each side of the Atlantic, a tentative agreement with the hypothesis of trans-Atlantic colonisation was formed (Lasota et al. 2004). Similarly, investigations of mtDNA using both the RFLP method and sequencing methodologies (Caporale et al. 1997, Sparagano et al. 2002) supported the trans-Atlantic colonisation concept, but discerned little or no population structure. These findings were interpreted as 
110 evidence of high levels of gene flow between areas. In their study of the COX1 mtDNA gene 111 of M. arenaria, based mainly in North America, Strasser \& Barber (2009) observed a unique 112 common haplotype in a single small sample from the Wadden Sea (Sylt, Germany - NSE).

113 While this observation could have been linked to a possible existence of European refugia, it

114 was dismissed on the basis of the relatively small number of individuals within samples,

115 resulting in low discovery of rarer haplotypes (Strasser \& Barber 2009).

116 In the current study sequences from a large section of the COX1 mitochondrial gene 117 were considered, together with sequences previously published by Strasser \& Barber (2009).

118 Genetic data from ten nuclear microsatellite DNA loci were also investigated. These

119 molecular data were analysed to investigate several eastern North American samples, a single

120 western North American and five European samples (the latter being the most intensive

121 coverage to date of European samples). Both mitochondrial and nuclear data were included to 122 test for correspondence in evolutionary inference between these two genomic systems.

123 Recently published microsatellite loci were included (St-Onge et al. 2011, Krapal et al.

124 2012), as their intensive polymorphism and high evolutionary rate make this marker type 125 ideal for determining routes of colonisation, quantifying relative numbers of founders and 126 determining contemporary population structure in donor and colonised areas.

127 In summary, the aims of the current study were to investigate genetic composition at 128 the $C O X 1$ gene and ten microsatellite loci in samples of $M$. arenaria from eastern and 129 western North America and from north Western Europe, and to test the hypothesis about the 130 origin of European colonization.

132 Materials and Methods

133 Sampling

134 Specimens of Mya arenaria $(\mathrm{n}=320)$ were sampled from eight intertidal locations 135 throughout the contemporary species range, in Ireland, North Wales, the Netherlands, eastern 136 Canada and three locations in the United States (Figure 1). Specimens were collected by 137 digging in the lower intertidal, or with a benthic hydraulic escalator dredge, at each site. Gill 138 tissue samples from each individual were preserved in 90\% molecular grade ethanol. Details 139 of sampling locations are shown in Figure 1 and Table 1. 
Ten to $16 M$. arenaria specimens representing the sampling locations covered in the current study (Table 1) were randomly chosen for mtDNA sequencing analysis. Genomic

143 DNA was extracted from gill tissue using QIAamp DNA mini Kit (QIAGEN). DNA quality and concentration was assessed by gel electrophoresis ( $0.8 \% 0.5 \mathrm{X}$ TBE agarose gel). For each of these samples, a 533 base pair (bp) region of the cytochrome oxidase subunit I mitochondrial DNA gene (mtDNA COXI) was amplified using the universal PCR primers HCO-2198 and LCO-1490 (Folmer et al. 1994). PCR amplifications were carried out in $50 \mu 1$ volumes, containing $5 \mu 1$ 10x Invitrogen Buffer, $3.5 \mu 1 \mathrm{MgCl}_{2}(50 \mathrm{mM}), 2 \mu 1 \mathrm{dNTPs}(5 \mathrm{mM}), 1$ $\mu \mathrm{l}$ of each primer $(10 \mathrm{pM} / \mu \mathrm{l}), 0.5 \mu \mathrm{l} \mathrm{BSA}(10 \mathrm{mg} / \mathrm{ml}), 0.8 \mu \mathrm{l}$ (4 U) Ampli-Taq polymerase

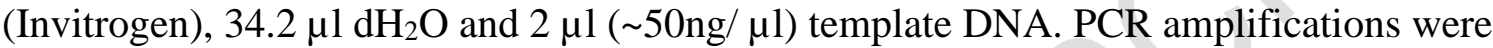
carried out on a Techne TC-Plus thermocycler as follows: $95^{\circ} \mathrm{C}$ for $15 \mathrm{~min}, 5 \mathrm{x}\left(95^{\circ} \mathrm{C}\right.$ for 60 sec, $50{ }^{\circ} \mathrm{C}$ for $60 \mathrm{sec}, 72{ }^{\circ} \mathrm{C}$ for $\left.60 \mathrm{sec}\right), 30 \mathrm{x}\left(95^{\circ} \mathrm{C}\right.$ for $60 \mathrm{sec}, 52{ }^{\circ} \mathrm{C}$ for $60 \mathrm{sec}, 72{ }^{\circ} \mathrm{C}$ for 60 sec), and $72{ }^{\circ} \mathrm{C}$ for 5 minutes.

Amplified products were checked for quality by gel electrophoresis $(1.5 \% 0.5 \mathrm{x}$ TBE agarose gel) and purified using EXOSAP-IT (Affymetrix, USB Products) purification kits. Purified products were bi-directionally sequenced using HCO-2198 and LCO-1490 primers and the Big Dye Terminator (V3.1) sequencing chemistry (Applied Biosystems) following manufacturer's recommendation. Cycle sequencing reactions were carried out on a Techne TC-Plus thermocycler as follows: $94{ }^{\circ} \mathrm{C}$ for $3 \mathrm{~min}, 25 \mathrm{x}\left(94{ }^{\circ} \mathrm{C}\right.$ for $10 \mathrm{sec}, 50{ }^{\circ} \mathrm{C}$ for $5 \mathrm{sec}, 60$ ${ }^{\circ} \mathrm{C}$ for $4 \mathrm{~min}$ ), and $8{ }^{\circ} \mathrm{C}$ for 10 minutes. Resulting sequencing products were purified by ethanol precipitation (125mM EDTA and 100\% molecular grade ethanol). Sequencing was carried out using an ABI 3730XL 96 capillary system DNA analyser (Applied Biosystems).

164 (Figure 1 and Table 2) were included in the current analysis. This allowed the integration of novel mtDNA sequencing data generated within this investigation to existing lineages identified in a previous study by Strasser \& Barber (2009).

Microsatellite DNA specimens ( $\mathrm{n}=320)$ using CHELEX-100 resin (Bio-Rad) extraction method. All samples were 
screened for ten microsatellite marker loci described by St-Onge et al. (2011) (Mar01, Mar04, Mar06, Mar07, Mar08) and Krapal et al. (2012) (Ma02, Ma06, Ma11, Ma14, Ma15), which were designed from M. arenaria microsatellite clone sequences from Genbank (accession numbers: JN850609.1, JN850610.1, JN850611.1, JN850612.1, JN850613.1, JN850614.1, JN850615.1, JN850616.1, JN850617.1) (Krapal et al. 2012). Primers were designed using Primer3Plus (Rozen \& Skaletsky 2000, Untergasser et al. 2007) with optimal primer length as $20 \mathrm{bp}$ and optimal $\mathrm{T}_{\mathrm{m}}$ at $60^{\circ} \mathrm{C}$. The forward primers were tailed with one of four universal dye-labelled tails in their 5' end: T3: PET: 5'AATTAACCCTCACTAAAGGG-3', M13 Reverse: NED: 5'GGATAACAATTTCACACAGG-3' (Diniz et al. 2007), Hill: 6FAM: 5'-

180 TGACCGGCAGCAAAATTG-3' (Tozaki et al. 2001) and Neomycin rev: VIC: 5'-

181 AGGTGAGATGACAGGAGATC-3'. PIG-tails were added to the 5' end of all the reverse primers (Brownstein et al. 1996). Primers were combined into two multiplex PCR reactions with Multiplex Manager 1.0 (Holleley \& Geerts 2009). out in reaction volumes of $5 \mu \mathrm{l}$, including $1 \mu \mathrm{l}$ of DNA (approximately $50 \mathrm{ng}$ ), $2.5 \mu \mathrm{l}$ of

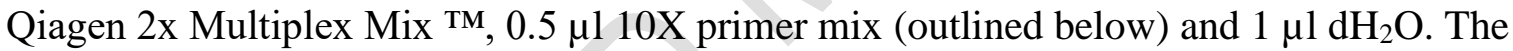
forward primer in each case incorporated a tail, to which a labelled tail would anneal during PCR. Final reaction primer concentrations were $0.2 \mu \mathrm{M}$ of forward (tailed) primer, $0.2 \mu \mathrm{M}$ of reverse primer (which was PIG-tailed) and $0.05 \mu \mathrm{M}$ of labelled tail primer. Four different

190 labelled tails were used (one for each channel, FAM, NED, VIC and PET). Tailing methods 191 for each locus are outlined in SI Table 1. Amplifications were performed on a Techne TCPlus thermocycler as follows: $15 \mathrm{~min}$ at $95{ }^{\circ} \mathrm{C}, 30 \mathrm{cycles}$ of $30 \mathrm{sec}$ at $94{ }^{\circ} \mathrm{C}, 90 \mathrm{sec}$ at $56{ }^{\circ} \mathrm{C}$,

193 and $60 \mathrm{sec}$ at $72{ }^{\circ} \mathrm{C}, 8$ cycles of $30 \mathrm{sec}$ at $94{ }^{\circ} \mathrm{C}, 90 \mathrm{sec}$ at $53{ }^{\circ} \mathrm{C}$, and $60 \mathrm{sec}$ at $72{ }^{\circ} \mathrm{C}$, with a

194 final step of $30 \mathrm{~min}$ at $60^{\circ} \mathrm{C}$. To minimise genotyping error, PCR amplification of each individual was repeated at least three times and three known genotype individuals were run on each plate for control purposes. All PCR products were run on an ABI 3730XL Genetic Analyser 16 capillary system (Applied Biosystems) and sized with internal lane standard (GENESCAN 500 LIZ, Applied Biosystems) using the program GENEMARKER v 1.6 199 (softgenetics). 


\section{Mitochondrial sequences}

Resulting sequences were checked for base call quality and ambiguity using

203 CHROMASPRO 150 (version 1.7.6) (Technelysium Pty Ltd.) and subsequently aligned using

204 'CLUSTAL W' implemented in BIOEDIT (version 7.1.9) (Hall 1999), alongside sequences

205 representing all haplotypes described by Strasser \& Barber (2009). Summary sample 206 diversity statistics including haplotype $(h)$ and nucleotide diversity $(\pi)$, and average number 207 of nucleotide differences $(k)$ between haplotypes were estimated using DNASP v5.1 (Rozas 208 et al. 2003). To assess the level of genetic structuring both on macro- (i.e. trans-Atlantic) and 209 micro- (North America and Europe) geographical levels, sample pairwise $\Phi_{\text {st }}$ estimators and 210 associated $P$ values were calculated in ARLEQUIN 3.01. Patterns of genetic subdivision both 211 at macro- and micro- geographical scales were evaluated using analysis of molecular variance 212 (AMOVA), also using ARLEQUIN 3.01. Statistical significance of the AMOVA was tested 213 by permutation (10,000). To examine the relationship among resulting mtDNA haplotypes 214 and to provide additional insights into the phylogeography of $M$. arenaria on both sides of 215 the Atlantic, a haplotypic network was constructed using the median-joining method (Bandelt 216 et al. 1999), implemented in Network 4.5.0.2 (fluxus-engineering.com, Fluxus Technology 217 Ltd. 2004). For this analysis, sequencing data from Strasser \& Barber (2009) was also 218 included for comparison.

Microsatellites

Within-sample statistics, including total number of alleles and mean number of alleles, expected and observed heterozygosity and allele richness (Kalinowski, 2004) were estimated using diveRsity (Keenan et al. 2013). The statistical significance of observed differences in the measures of allelic richness between samples (pairwise tests) was assessed using a sign test (Wilcoxon signed-rank tests) across loci as suggested by Kalinowski (2005).

Deviations from Hardy-Weinberg equilibrium (HWE) were assessed using exact probability tests implemented in GENEPOP 3.4 (Raymond \& Rousset, 1995). Significance levels for multiple comparisons were adjusted using standard Bonferroni correction (Rice 1989). Because null alleles can result in an underestimation of within-population genetic variation, 
230 loci that deviated from HWE, with heterozygote deficiencies, were evaluated for the

231 existence of null alleles following approach implemented in MICRO-CHECKER 2.2.3 (van

232 Oosterhout et al. 2004).

233 Genetic divergence among samples was compared using $F_{\mathrm{ST}}$ (Weir \& Cockerham

234 1984), estimated using diveRsity (Keenan et al. 2013), and statistical significance was

235 assessed by bootstrapping loci $(5,000)$. Patterns of nuclear genetic subdivision observed both

236 at macro- and micro- geographical scales were evaluated using analysis of molecular variance

237 (AMOVA) also using ARLEQUIN 3.01 with 10,000 permutations.

238 To further investigate the presence and patterns of population sub-structuring within

239 the sample, an unrooted neighbour joining (NJ) tree was created based on Nei et al. (1983)

240 genetic distances. Genetic distances and bootstrap values $(10,000)$ were calculated using

241 Populations 1.2.3.1. A tree was then drawn using Figtree

242 (http://tree.bio.ed.ac.uk/software/figtree/).

243 As an additional approach to examine the patterns of population genetic within the

244 data, the Bayesian analytical framework implemented in the programme STRUCTURE

245 (Pritchard et al. 2000) was also used. This framework allows for the identification of genetic

246 partitioning (i.e. genetic sub-structuring) within a sample for which no a priori hypothesis of

247 population structuring exists. Thus, given a sample set consisting of genotypic data from a

248 number of specimens, the analytical framework estimates the minimum number of Mendelian

249 populations (i.e. independent genetic entities) that best explains the data. Here, the

250 STRUCTURE analysis was carried out using a hierarchical approach, which was primarily

251 intended to identify major genetic evolutionary lineages within the data and subsequently

252 refining these to the population level. This analysis was carried out as follows: 1) using the

253 the complete data set, STRUCTURE runs were set for $k$ varying from 1 to 10 (20 interactions

254 for each $k$ value), with 100,000 burn-in iteractions, followed by 100,000 MCMC iteractions

255 for each independent run. STRUCTURE analysis was carried out using the admixture model

256 with correlated allele frequencies. Group matching among independent run interactions was

257 carried out using CLUMP v.1.1.2b (Jakobsoh \& Rosenberg 2007) employing the "greedy"

258 algorithm with random input orders and 20,000 repeats. In each case, the optimal $k$ was

259 determined using the ad-hoc method of Evanno et al. (2005). 2).Following this initial run, in

260 order to identify further genetic sub-structuring within the data (i.e. sub-groups within the

261 main groups), STRUCTURE was independently run with genotypic data from each of the

262 main groups separately. In each instance, the same approach/parameters adopted for the 
whole data set were used. If additional substructuring was identified, STRUCTURE was again independently run against samples representing each sub-group using same approach/parameters. This iterative/hierarchical approach was repeated until no further substructuring was evident from the data. Results of this hierarchical analysis were summarsed in graphical format using STRUCTURE plots. Finally, as an alternative non-parametric approach to assess the existence of population sub-structuring within the data, a Factorial Component Analysis (FCA) was carried out using GENETIX 4.05 (Belkhir et al. 1996-2004). The results of this analysis were summarised using a three dimensional plot generated in MATLAB 2.04 (The Mathworks Inc.) using the scatter three-function.

\section{Results}

\section{Mt DNA COXI Region}

The alignment of all COXI gene sequences (i.e. 84 generated in the present study in addition to the 212 sequences from Strasser \& Barber (2009) revealed 34 haplotypes of which 27 were previously described by Strasser \& Barber (2009) and seven were novel (Table 3) (KU720416, KU720417, KU720418, KU720419, KU720420, KU720421, KU720422, KU720423, KU720424, KU720425, KU720426, KU720427, KU720428, KU720429, KU720430). Haplotype A was the only one to be shared among all samples on both sides of the Atlantic and in the Pacific. It was predominant in all except for the samples from Ireland (BB \& FF). As has been reported by Strasser \& Barber (2009), with few exceptions, most haplotypes are restricted to particular sampling locations, occurring once only. Among the notable exceptions was haplotype $\mathrm{B}$, which was relatively common throughout the sampling range but appears to be particularly common in Europe, and haplotype E which, with one exception (Canada - C), was restricted to European samples. Of the seven novel haplotypes described in the present study, five were restricted to North America and two (AB and AC) were restricted to Europe.

The median-join network depicting the genetic relationship among haplotypes, revealed a star-shaped phylogeny (Figure 2). In most cases, haplotypes differed from each other by a single mutational step stemming from haplotype A.

\section{Within sample variability}



which were fixed for haplotype A to 0.800 and 0.894 in Maryland (MLMR) and Bannow Bay (BB) respectively with an average of 0.422 (Table 2 ). Nucleotide diversity ( $\pi$ ) was relatively low for all localities, ranging from 0.00023 in the Canadian sample (C) to 0.00245 in the Miles River (MLMR) group. The values for the average number of nucleotide differences $(k)$ ranged from zero in Wales (W) and 0.125 in Canada (C) to 1.303 in the Miles River (MLMR) sample (Table 2).

Among sample variability

After standard Bonferroni correction, pairwise inter-population $\Phi_{\mathrm{st}}$ comparisons revealed certain samples of $M$. arenaria to be statistically significantly different from each other (Table 4), including the Irish samples (BB \& FF) with Welsh (W) and Maryland (MLEB \& MLMR) M. arenaria, and the Canadian sample (C) with the Flaxfort (FF) and Miles River (MLMR) Maryland individuals. The Netherlands (N) sample was not shown to be statistically significantly different from any other areas using this method. In the hierarchical AMOVA, 90\% of mtDNA COX1 variation was found within samples, whereas $7.9 \%$ and $2.1 \%$ of total haplotype frequency variation (both values statistically significant from zero) was represented by variation between European and North American samples and among samples within regions respectively (SI Table 2).

Microsatellites

\section{Intra sample parameters}

Three hundred and twenty $M$. arenaria from eight geographical sites across the species range were genotyped at ten microsatellite loci (SI Table 6). No linkage disequilibrium was observed between locus pairs and all ten loci were polymorphic. The three loci that deviated from HWE with heterozygote deficiencies (Ma 02, Ma 06 and Ma 15) were positively identified as possessing null alleles in MICRO-CHECKER 2.2.3 (van

318 Oosterhout et al. 2004). Since the apparent presence of null alleles at these three loci had a

319 negligible effect on the estimation of overall $F_{\mathrm{ST}}$ (uncorrected value 0.058 and corrected 320 value 0.057 ), all ten loci were used in calculation of pairwise $F_{\text {ST }}$ values (Table 5). The average number of alleles per sample varied from 7.2 in the Welsh sample (W), to 24.8 in the Miles River, Maryland sample (MLMR) (Table 1, SI Table 3), with the total average number of alleles per locus of 15 , and a total of 355 alleles being detected overall. Across all loci 
sampled, alleles unique to an area were present in small numbers in all sites except the Welsh sample (W) (SI Table 4).

Observed and expected within-sample heterozygosity values varied from 0.678 (Flaxfort - FF) to 0.914 (Oregon - NEP), and from 0.706 (Wales - W) to 0.901 (Maryland samples - MLEB \& MLMR) (Table 1, SI Table 3). The highest percentage of unique alleles present in an area was found in the Oregon sample (NEP) of M. arenaria, and the lowest in the Welsh sample (W) (SI Table 4). Genetic variability as measured by allelic richness $\left(\mathrm{R}_{\mathrm{s}}\right)$ ranged from 11.1 in the two Maryland sites (MLEB \& MLMR), to 5.6 in the Welsh sample (W), with a mean allelic richness of 8.41. Results from the Wilcoxon signed-rank tests for differences in allele diversity (i.e. allele richness) among samples indicates significant statistical outcomes between all pair-wise comparison involving samples from North America and Europe ( $P<0.01$ in all instances). Thus, samples from North America consistently displayed significantly higher levels of allele diversity in comparison to European samples. There were no significant differences in allele richness among pairwise comparison involving North American samples only. Among the European samples, however, the Netherlands sample was found to display significantly higher levels of allele diversity $(P<0.01)$ in comparison to all other European samples, which in turn, displayed similar levels of allele diversity (i.e. not statistically significant).

\section{Inter sample comparisons}

Genetic differentiation over the eight softshell clam samples was significant at an overall value of 0.0224 (95\% CI 0.0140 - 0.0341). Pairwise $F_{\text {ST }}$ values ranged from the single not statistically significant 0.0017 between the two Maryland sites (MLEB \& MLMR), to 0.113 and 0.101 between Welsh (W) and Canadian (C), and Welsh (W) and Flaxfort (FF) $M$. arenaria respectively (Table 5). All samples of $M$. arenaria were significantly different from each other, excepting those from the two Maryland sites (MLEB \& MLMR).

The population structuring suggested by the pairwise $F_{\mathrm{ST}}$ analysis was further supported in the un-rooted neighbour-joining tree based on inter sample $\mathrm{D}_{\mathrm{a}}$ values, and showed the European and North American samples to be clearly separated, with the Netherlands (N) sample being in an intermediate position (Figure 3). Samples of M. arenaria from the two Irish sites, Bannow Bay (BB) and Flaxfort (FF), clustered together on the neighbour-joining tree, as did the two samples from Maryland, North America (MLEB \& 
MLMR). The hierarchical STRUCTURE plots (Figure 4) provide further support to these inter sample relationships. Samples from the two continents separated at the first level (i.e. Level 0 in Figure 4). Significant within continent variation was also identified at the second hierarchical level (Level 1, groups 1 and 2) with no further obvious differentiation between the two Maryland or Irish samples (i.e. third hierarchical level - Level 2). The significant level of population genetic structuring observed with pairwise $F_{\mathrm{ST}}$ estimates and confirmed from both neighbour-joining and STRUCTURE analyses was further supported by the independent results of Factorial Component Analysis (SI Figure 1), which shows clear separation among samples from Europe and North America in addition "within major regions" sub structuring (SI Figure 1).

Hierarchical AMOVA analyses corroborate previous analysis by indicating significant differences in genetic partitioning of $M$. arenaria at all levels of geographic organisation (with regional partitioning as used above for COXI data), between the two regions, Europe and North America, among populations within regions, and within populations (SI Table 5). As with mtDNA COX1 AMOVA results, most variation was due to differentiation within populations $(88.29 \%)$, while $5.48 \%$ and $6.23 \%$ of total variation was represented by variation among Europe and North American samples, and among populations within regions respectively.

\section{Discussion}

As noted in the Introduction, previous studies of M. arenaria failed to demonstrate significant inter- and intra-continental differences between samples. Conversely, in the present study virtually all samples were significantly different for pairwise multi-locus microsatellite $F_{\mathrm{ST}}$ values, except those in close proximity in Chesapeake Bay (Table 5). The greatest difference was between samples from either side of the Atlantic (see AMOVA results in SI Table 4). This suggests that all but two of these samples should be regarded as largely distinct populations, with little contemporary gene flow between them.

In the present investigation, the utilisation of a combination of two independent molecular methods in this species was novel. Another innovation with these markers, which have previously proven to be discriminatory in eastern North America (Strasser \& Barber 
2009, St-Onge et al. 2011), was the inclusion of more than one European sample. This allows consideration of aspects such as possible colonisation modes and routes, and population variability within Europe. Both molecular methods indicate major or exclusive colonisation from eastern North America, in that European samples shared the same common mitochondrial haplotypes or common microsatellite alleles with eastern North American samples. In addition, North American samples displayed statistically significant higher levels of genetic diversity in comparison to European samples in a pattern that is consistent with source populations. Thus, we suggest that, based on current data, eastern North American populations were the major source of post Pleistocene colonisers to northern Europe.

\section{Routes of European colonisation}

Previous authors (Petersen et al. 1992, Strasser 1999) have suggested that M. arenaria was introduced into Europe by Vikings returning to Europe in pre-Columbian times.

Alternatively, natural colonisation could have occurred by larval drift from west to east via northern coastal locations. Future sampling of $M$. arenaria in the more northerly parts of the contemporary range in eastern North America and western Europe, and in transitional regions such as Iceland and Greenland, might clarify the possible routes of colonisation, as has been the case in the molecular investigation of Arctica islandica (Dahlgren et al. 2000), Cerastoderma edule (Krakau et al. 2012), Macoma balthica (Luttikhuizen et al. 2003), and Littorina saxatilis (Panova et al. 2011).

Regardless of whether European colonisation was human mediated or natural, data obtained in the current study would suggest that colonisation occurred from the north of the eastern North American range. Analysis of the relationship at microsatellite loci between the M. arenaria samples suggests a closer relationship between the Prince Edward Island sample (north of the eastern North American range) and the Netherlands sample (North Sea, Europe), than for samples from further south in the eastern North American range (Maryland, USA) (Figure 3 and SI Fig 1).

Assuming that variability decreases from the point of first colonisation (Hewitt 2000), levels of microsatellite variability (i.e. allele diversity) and genetic similarity observed in the four European samples may give some indication of the sequence of north western European colonisation. The average level of genetic diversity was significantly higher in the North Sea (Netherlands) sample, than in other European samples (from the Celtic Sea, southern Ireland 
and Wales (Table 1)). Following the theory put forward by Hewitt (2000), this suggests that the North Sea could have been the area of first European colonisation from which other areas would be subsequently colonised. While no statistically significant differences were observed among the other European samples, it is interesting to note the sample from Wales displays the lowest level of genetic diversity numerically, thus suggesting that this area may have been the last to be colonised. The resulting neighbour joining (NJ) tree (Figure 3) and the results from the STRUCTURE analysis (Figure 4) support this interpretation, as do pairwise $F_{\text {ST }}$ values for microsatellites (Table 5). Indeed, the $F_{\mathrm{ST}}$ estimates might seems to suggest a 'stepping stone' sequence of progressive colonisation, similar to that proposed by Allendorf \& Luikart (2008).

The situation is far less clear cut for the mitochondrial data, possibly because of the lower variability observed in $C O X 1$ sequences and the use of substantially lower sample sizes. Mitochondrial DNA pairwise $\Phi_{\text {st }}$ estimates for Canada compared with three of European samples (the Netherlands, Bannow Bay and Flaxfort) provided the same trend of increasing $\Phi_{\text {st }}$ estimates as observed for the microsatellites (Table 5). In contrast, the pairwise mitochondrial DNA $\Phi_{\text {st }}$ between Canada and Wales was zero, while an $F_{S T}$ value of 0.113 for microsatellite data from the same samples was higher than those between the Canadian and other European samples (Table 5). The examination of genetic variability ( $h$ values) for COX1 also showed a complex pattern (Table 2), where $h$ values of the Irish samples were particularly high. These results, however, have to be interpreted with caution because of the small sample involved. One possibly hypothesis is that at $C O X 1$, the Irish samples displays evidence of a separate colonisation event, either from eastern North America or from a possible southern European refugium (Maggs et al, 2008)

\section{Possible European refugia?}

The concept that European refugia, if they existed, should have occurred at the south of the range assumes that coastal marine species spread northwards post-glacially (Hewitt, 2000). Many marine species, including the northern quahog Mercenaria mercenaria (Baker et al. 2008), American lobster Homarus americanus (Kenchington et al. 2009), the marine gastropod Acanthinucella spirata (Hellberg et al. 2001), and the dog whelk Nucella ostrina

445 (Marko 2004), appear to conform to the model proposed by Hewitt (2000). However, it has 446 been proposed that several marine species instead had northern peri glacial refugia, on the 
basis of high genetic variability in contemporary northern populations. These include the ocean quahog Arctica islandica (Dahlgren et al. 2000), Macoma balthica (Luttikhuizen et al. 2003), Cerastoderma edule (Krakau et al. 2012), Pagurus longicarpus (Young et al. 2002) and Littorina saxatilis (Panova et al. 2011). In addition, peri-glacial refugia have been suggested for many other marine species including Carcinus maenas (Roman \& Palumbi 2004), seaweed species (Hoarau et al. 2007, Olsen et al. 2010, Coyer et al. 2011), the common shrimp, Crangon crangon (L) (Luttikhuizen et al. 2008), the genus Patella (SaPinto et al. 2005) and tubiferous polychaetes (Jolly et al. 2006).

It is interesting to note that the molecular data produced by St-Onge et al. (2013) suggest a southern refugium for $M$. arenaria in eastern North America. In the present study, it was not feasible to determine whether there has also been a limited contribution from one or more refugia on European shores, if the species did persist in Europe during the Pleistocene. While some haplotypes were almost or totally exclusive to Europe (see Irish samples in Table 3 ), the majority were only one mutational step removed from haplotypes common in eastern North America (see Figure 2). For microsatellites, only a minority of rare alleles was exclusive to European samples. More extensive European sampling, particularly further south in the range, will be necessary to address this question.

The level of genetic variability at the microsatellite loci, observed in the Pacific North American sample is informative in the context of size of introductions. In this case there is documented evidence of recent human introduction from the southern part of the eastern North American range, when a large number of $M$. arenaria were introduced to areas through the commercial oyster industry, and dedicated plantings were made to initiate a commercial fishery (Hanna, 1966, Carlton, 1989, Strasser 1999). The sample analysed in the present study from Oregon on the Pacific coast had a level of microsatellite variability similar to that from Maryland on the Atlantic coast, giving genetic confirmation of a large introduction from an eastern North American area. In contrast, the European clam samples showed substantially lower microsatellite variability, suggesting a lower number of individuals introduced to this area (see Table 1). 
478 America to Europe. The results from the analysis of COX1 sequences are less clear than those

479 of microsatellites, which provided better support for discrimination among samples within

480 continents in comparison to the single mitochondrial region. Interestingly, however, both

481 mitochondrial DNA and microsatellites provide almost equal support to the inter region

482 (continent) differences.

483 What is clearly demonstrated by the present results, is that the use of different marker

484 types provides more detailed insights about mode of colonisation and contemporary

485 population structure. We therefore suggest that a genomic approach be applied to the

486 investigation of $M$. arenaria in the future, perhaps by identifying and screening a large

487 number of SNPs (Beaumont \& Balding 2004). This, in addition to modern statistical

488 approaches based on Bayesian hypothesis inference (e.g. Cornuet et al 2014) may further

489 clarify the ecology and previous movements of what is now an ecologically important and

490 abundant soft sediment infaunal species in north western Europe. It would also provide

491 genomic information that would be of use in $M$. arenaria aquaculture, which is widespread

492 and commercially important in North America, and is to be developed in Europe.

493 Acknowledgements:

494 This project was part-funded by the Ireland Wales Programme 2007-2013 INTERREG 4A

495 European Regional Development Fund.

496 Many thanks to Chris Dungan, John Chapman, Dante Mateo, Pauline Kamermans, Ruth

497 Stockdale, Allen Whitaker, Eileen Dillane, and Jens and Nettan Carlsson for providing $M$.

498 arenaria samples and practical help.

499 Caroline Bradley and Philip McGinnity were supported by the Beaufort Marine Research

500 Award in Fish Population Genetics funded by the Irish Government under the Sea Change

501 Programme.

502

503 References:

504 Allendorf FW, Luikart G (2008) Conservation and the Genetics of Populations. Malden, MA, $505 \quad$ Blackwell. 
506

507

508

509

510

511

512

513

514

515

516

517

518

519

520

521

522

523

524

525

526

527

528

529

530

531

532

Arias-Pérez A., Fernández-Tajes J, Gaspar M.B, Méndez J (2012) Isolation of Microsatellite Markers and Analysis of Genetic Diversity among East Atlantic Populations of the Sword Razor Shell Ensis siliqua: A Tool for Population Management. Bio Genetics $50(5-6): 397-415$.

Baker P, Austin JD, Bowen BW, Baker SM (2008) Range-wide population structure and history of the northern quahog (Merceneria merceneria) inferred from mitochondrial DNA sequence data. ICES J Mar Sci 65(2): 155-163.

Bandelt HJ, Forster P, Rohl A (1999) Median-joining networks for inferring intraspecific phylogenies. Mol Biol Evol 16 (1): 37-48.

Beaumont MA, Balding DJ (2004) Identifying adaptive genetic divergence among populations from genome scans. Mol Ecol 13(4): 969-980.

Beebee TJC, Rowe G (2008) An introduction to molecular ecology. Oxford University Press.

Belkhir K, Borsa P, Chikhi L, Raufaste N, Bonhomme F (1996-2004) GENETIX 4.05, logiciel sous Windows TM pour la génétique des populations. Laboratoire Génome, Populations, Interactions, CNRS UMR 5000, Université de Montpellier II, Montpellier (France).

Blakeslee A, Byers J, Lesser M (2008) Solving cryptogenic histories using host and parasite molecular genetics: the resolution of Littorina littorea's North American origin. Mol Ecol 17: 3684-2696.

Blakeslee A, Byres J (2008) Using parasites to inform ecological history: comparisons among three congeneric marine snails. Ecology 89: 1068-1078.

Bologa AS, Bodeanu N, Petran A, Tiganus V, Zaitsev YP (1995) Major modifications of the Black Sea benthic and planktonic biota in the last three decades. Bulletin de l'Institut Océanographique: 85-110.

Brawley S, Coyer J, Blakeslee A, Hoarau G, Johnson L, Byers J, Stam W, Olsen J (2009) Historical invasions of the intertidal zone of Atlantic North America associated with distinctive patterns of trade and emigration. Proc Nat Acad Sci, Early edition 1-6. 
533

534

535

536

537

538

539

540

541

542

543

544

545

546

547

548

549

550

551

552

553

554

555

556

557

558

Briski E, Ghabooli S, Bailey SA, MacIsaac HJ (2012) Invasion risk posed by macroinvertebrates transported in ships' ballast tanks. Biol Invasions: 1-8.

Brownstein MJ, Carpten JD, Smith JR (1996) Modulation of non-templated nucleotide addition by Taq DNA polymerase: primer modifications that facilitate genotyping. BioTechniques 20: 1004-1010.

Caporale DA, Beal BF, Roxby R, Van Beneden R.J (1997) Population structure of Mya arenaria along the New England coastline. Mol Mar Biol Biotech 6(1): 33-39.

Carlton JT (1989) Man's role in changing the face of the ocean: biological invasions and implications for conservation of near-shore environments. Conserv Biol 3: 265-273.

Chapman J (2007) The mysterious periwinkle (Littorina littorea): Norse or later introduction from Europe? Arc Stud Centre News 14:22.

Chapman JW, Blakeslee AMH, Carlton JT, Bellinger MR (2008) Parsimony dictates a human introduction: on the use of genetic and other data to distinguish between the natural and human-mediated invasion of the European snail Littorina littorea in North America. Biol Invasions 10(2): 131-133.

Chapman JW, Carlton JT, Bellinger MR, Blakeslee AMH (2007) Premature refutation of a human-mediated marine species introduction: the case history of the marine snail Littorina littorea in the northwestern Atlantic. Biol Invasions 9: 737-750.

Conde A, Novais J, Domínguez J (2010) Southern limit of distribution of the soft-shell clam Mya arenaria on the Atlantic East Coast. Biol Invasions 12(3): 429-432.

Cornuet J-M, Pudlo P, Veyssier J, Dehne-Garcia A, Gautier M, Leblois R, Marin J-M, Estoup A (2014) DIYABC v2.0: a software to make Approximate Bayesian Computation inferences about population history using Single Nucleotide Polymorphism, DNA sequence and microsatellite data. Bioinformatics 30(8): 1187-1189.

Coyer JA, Hoarau G, Van Schaik J, Luijckx P, Olsen JL (2011) Trans- Pacific and transArctic pathways of the intertidal macroalga Fucus distichus L. reveal multiple glacial 

38(4):756-771.

561 Crocetta F, Turolla, E (2011) Mya arenaria Linné, 1758 (Mollusca: Bivalvia) in the Mediterranean Sea: its distribution revisited. J of Biol Res-Thessaloniki: 16 188-193.

563

564

565

566

567

568

569

570

571

572

Dahlgren TG, Weinberg JR, Halanych KM (2000) Phylogeography of the ocean quahog (Arctica islandica): influences of paleoclimate on genetic diversity and species range. Mar Biol 137(3): 487-495.

Diniz F M, Iyengar A, Sarmanho da Costa Lima P, Maclean N, Bentzen P (2007) Application of a double-enrichment procedure for microsatellite isolation and the use of tailed primers for high throughput genotyping. Gen Mol Biol 30: 380-384.

Dupont L, Ellien C, Viard F (2007) Limits to gene flow in the slipper limpet Crepidula fornicata as revealed by microsatellite data and a larval dispersal model. Mar Ecol Prog Ser 349: 125-138.

Evanno G, Regnaut S, Goudet J (2005) Detecting the number of clusters of individuals using the software STRUCTURE: a simulation study. Mol Ecol 14: 2611-2620.

Folmer O, Black M, Hoeh W, Lutz R, Vrijenhoek R (1994) DNA primers for amplification of mitochondrial cytochrome c oxidase subunit I from diverse metazoan invertebrates. Mol Mar Biol Biotech 3(5): 294.

Hall TA (1999) BioEdit: a user-friendly biological sequence alignment editor and analysis program for Windows 95/98/NT. Nucleic Acids symposium series.

Hanna GD (1966) Introduced mollusks of western North America. Occ Papers Calif Acad Sci 48: $\mathrm{t}-108$.

Harley CDG, Anderson KM, Lebreton CA-M, MacKay A, Ayala-Díaz M, Chong SL, Pond LM, Maddison JHA, Hung BHC, Iversen SL (2013) The introduction of Littorina littorea to British Columbia, Canada: potential impacts and the importance of biotic resistance by native predators. Mar Biol: 1-13. 
585

586

587

588

589

590

591

592

593

594

595

596

597

598

599

600

601

602

603

604

605

606

607

608

609

610

Hellberg D, Balch P, Roy K (2001) Climate-driven range expansion and morphological evolution in a marine gastropod. Science 292: 1707-1710.

Hewitt GM (1999) Post-glacial re-colonisation of European biota. Biol J Linn Soc 68:87112.

Hewitt G (2000) The genetic legacy of the Quaternary ice ages. Nature 405(6789): 907-913.

Hoarau G, Coyer JA, Veldsink JH, Stam WT, Olsen JL (2007) Glacial refugia and recolonization pathways in the brown seaweed Fucus serratus. Mol Ecol 16:36063616.

Holleley CE, Geerts PG (2009) Multiplex Manager 1.0: a crossplatform computer program that plans and optimizes multiplex PCR. BioTechniques 46 (7): 511-517.

Jolly MT, Viard F, Gentil F, Thiébaut E, Jollivet D (2006) Comparative phylogeography of two coastal polychaete tubeworms in the Northeast Atlantic supports shared history and vicariant events. Mol Ecol 15(7): 1841-1855.

Kalinowski ST, (2004) Counting alleles with rarefaction: Private alleles and hierarchical sampling designs. Conserv Genet 5:539-543.

Kalinowski ST, (2005) HP-RARE 1.0: a computer program for performing rarefaction on measures of allelic richness. Mol Ecol Notes 5:187-189.

Keenan K, McGinnity P, Cross TF, Crozier WW, Prodohl PA (2013) diveRsity: An R package for the estimation and exploration of population genetics parameters and their associated errors. Methods Ecol Evol 4 (8): 782-788.

Kenchington EL, Harding EL, Jones MW, Prodohl PA (2009) Pleistocene glaciation events shape genetic structure across the range of the American lobster, Homarus americanus. Mol Ecol 18(8): 1654-1667.

Krakau M, Jacobsen S, Jensen KT, Reise K (2012) The cockle Cerastoderma edule at Northeast Atlantic shores: genetic signatures of glacial refugia. Mar Biol 159: 221230. 
611 Krapal AM, Popa OP, Iorgu EI, Costache M, Popa LO (2012) Isolation and Characterization

612

613

614

615

616

617

618

619

620

621

622

623

624

625

626

627

628

629

630

631

632

633

634

635

636

637 of New Microsatellite Markers for the Invasive Softshell Clam, Mya arenaria (L.) (Bivalvia: Myidae). Internatl J Mol Sci 13(2): 2515-2520.

Lasota R, Hummel H, Wolowicz M (2004) Genetic diversity of European populations of the invasive soft-shell clam Mya arenaria (Bivalvia). J Mar Biol Assoc United Kingdom 84(5): 1051-1056.

Levinton J (1973) Genetic variation in a gradient of environmental variability: marine bivalvia (Mollusca). Science, 180(81):75-6.

Linnaeus C (1758) Systema Naturae per regna tria naturae, secundum classes, ordines, genera, species, cum characteribus, differentiis, synonymis, locis. Editio decima, reformata. Laurentius Salvius: Holmiae. ii, 824 pp.

Luttikhuizen, P. C., Campos, J., van Bleijswijk, J., Peijnenburg, K. T., \& van der Veer, H. W. (2008). Phylogeography of the common shrimp, Crangon crangon (L.) across its distribution range. Molecular phylogenetics and evolution, 46(3), 1015-1030.

Luttikhuizen PC, Drent J, Van Delden W, Piersma T (2003) Spatially structured genetic variation in a broadcast spawning bivalve: quantitative vs molecular traits. J Evol Biol 16(2): 260-272.

MacNeil FS (1965) Evolution and distribution of the genus Mya, and tertiary migrants of mollusca. Geol Survey Prof Paper: 483-G, 1-51.

Maggs CA, Castilho R, Foltz D, Henzler C, Jolly MT, Kelly J, Olsen J, Perez KE, Stam W, Väinölä R (2008) Evaluating signatures of glacial refugia for North Atlantic benthic marine taxa. Ecology 89(sp11): 108-122.

Marko PB (2004) 'What's larvae got to do with it?' Disparate patterns of post-glacial population structure in two benthic marine gastropods with identical dispersal potential. Mol Ecol 12:597-611.

Morgan RP, Block SB, Ulanowicz NI, Buys C (1978) Genetic variation in the soft-shelled Clam, Mya arenaria. Estuaries and Coasts: 1. 
638

639

640

641

642

643

644

645

646

647

648

649

650

651

652

653

654

655

656

657

658

659

660

661

662

663

664

665

Nei M, Tajima F, Tateno Y (1983) Accuracy of estimated phylogenetic trees from molecular data. J Mol Evol 19(2): 153-170.

Olsen JL, Zechman FW, Hoarau G, Coyer JA, Stam WT, Valero M, Aberg P (2010) The phylogeographic architecture of the fucoid seaweed Ascophyllum nodosum: an intertidal 'marine tree' and survivor of more than one glacial-interglacial cycle. J Biogeog 37:842-856.

Panova M, Blakeslee AMH, Miller AW, Mäkinen T, Ruiz GM, Johannesson K, André C (2011) Glacial history of the North Atlantic marine snail, Littorina saxatilis, inferred from distribution of mitochondrial DNA lineages. PLoS ONE 6(3): e17511.

Petersen KS, Rasmussen KL, Heinemeier J, Rud N (1992) Clams before Columbus? Nature (London) 359: 679.

Pritchard JK, Stephens M, Donnelly P (2000) Inference of population structure using multilocus genotype data. Genetics 155: 945-959.

Raymond M, Rousset F (1995) GENEPOP (version 1.2): population genetics software for exact tests and ecumenicism. J Hered 86: 248-249.

Roman J, Palumbi SR (2004) A global invader at home: population structure of the green crab, Carcinus maenas, in Europe. Mol Ecol 13:2891-2898.

Rozas J, Sánchez-DelBarrio JC, Messeguer X, Rozas R (2003) DnaSP, DNA polymorphism analyses by the coalescent and other methods. Bioinformatics 19(18): 2496-2497.

Rozen S, Skaletsky H (2000) Primer3 on the WWW for general users and for biologist programmers. Methods Mol Biol 132: 365-386.

Rice WR (1989) Analyzing tables of statistical tests. Evolution 43 (1): 223-225.

Ruiz GM, Carlton JM, Grosholz ED, Hines AH (1997) Global Invasions of Marine and Estuarine Habitats by Non-Indigenous Species: Mechanisms, Extent, and Consequences. Amer Zoo 37:621-632.

Sa-Pinto A, Branco M, Harris DJ, Alexandrino P (2005) Phylogeny and phylogeography of the genus Patella based on mitochondrial DNA sequence data. J Exp Mar Biol Ecol 325: 95-110. 
666

667

668

669

670

671

672

673

674

675

676

677

678

679

680

681

682

683

684

685

686

687

688

689

690

691

692

Sparagano OAE, Purdom I, Priest FG, Kingston PF (2002) Molecular characterization of the bivalves Mya arenaria, Mya truncata and Hiatella arctica. J Mollusc Studies 68(2): 190.

St-Onge P, Parent E, Sévigny J-M, Tremblay R, Rioux-Paré R (2011) Isolation and characterization of eight novel microsatellite markers for the softshell clam (Mya arenaria). Mol Ecol Res.

St-Onge, P, Sevigny, JM, Strasser C, Tremblay R (2013) Strong population differentiation of softshell clams (Mya arenaria) sampled across seven biogeographic marine ecoregions: possible selection and isolation by distance. Mar Biol DOI $10.1007 / \mathrm{s} 00227=012-2157-5: 1-17$.

Strasser M (1999) Mya arenaria — an ancient invader of the North Sea coast. Helgo Mar Res 52(3): 309-324.

Strasser C, Barber P (2009) Limited genetic variation and structure in softshell clams (Mya arenaria) across their native and introduced range. Cons Gen 10(4): 803-814.

Strauch F (1972) Phylogenese, adaption und migration eineger nordischer mariner Mollusken genera (Neptunea, Panomya, Cyrtodaria und Mya) (in German). Abh Senck Natur Gesell: 531, 1-211.

Tozaki T, Mashima S, Hirota K (2001) CharMiura, N., Choi-Miura, N. H., Tomita, M. 2001. Chacterization of equine microsatellites and microsatellite-linked repetitive elements (eMLREs) by efficient cloning and genotyping methods. DNA Res 8: 33-45.

Untergasser A, Nijveen H, Rao X, Bisseling T, Geurts R, Leunissen JA (2007) Primer3Plus, an enhanced web interface to Primer3. Nuc Acid Res 35: W71-74.

Van Oosterhout C, Hutchinson WF, Wills DPM, Shipley P (2004) Microchecker: software for identifying and correcting genotyping errors in microsatellite data. Mol Ecol Notes 4(3): 535-538.

Weir BS, Cockerham CC (1984) Estimating F-Statistics for the analysis of population structure. Evolution 38 (6): 1358-1370. 
693 Weston S, Buttner JK (2010) Softshell Clam Culture: Basic Biology and General Culture Considerations. NRAC Publication 201.

695 Young A, Torres C, Mack J, Cunningham C (2002) Morphological and genetic evidence for 696 vicariance and refugium in Atlantic and Gulf of Mexico populations of the hermit crab Pagurus longicarpus. Mar Biol 140(5): 1059-1066.

698 Zaitsev Y, Mamaev V (1997) Marine biological diversity in the Black Sea: A Study of 699 Change and Decline. United Nations Publications, New York.

700

701

702

703

704 
a)

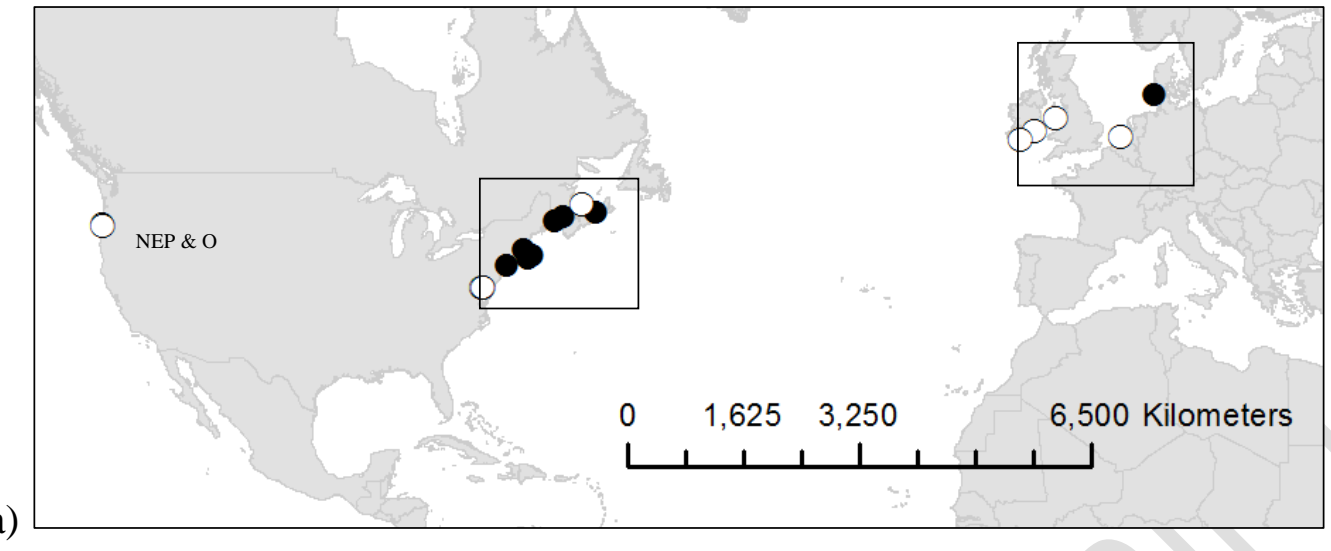

b)

c)
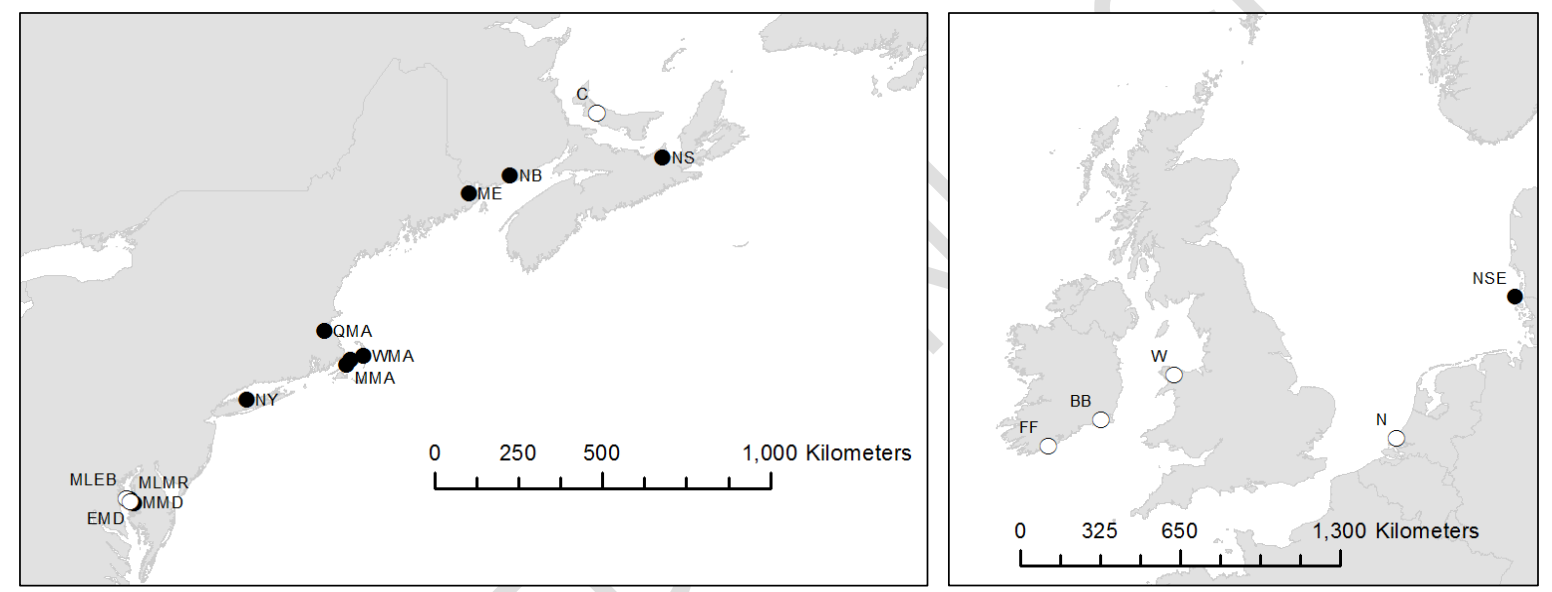

707 Figure 1. Sampling locations of Mya arenaria (a) throughout the range in the (b) western

708 North Atlantic region and (c) on western European coast. Black circles represent samples

709 analysed in the previous study of Strasser and Barber (2009) and white circles samples

710 collected for the present study. Sampling codes for current samples are as provided in Table

711 2. The NEP site in Oregon is obscured in Figure 1 (a) and some other overlap of

712 neighbouring sites occurs in Table 1 (a) and (b) 


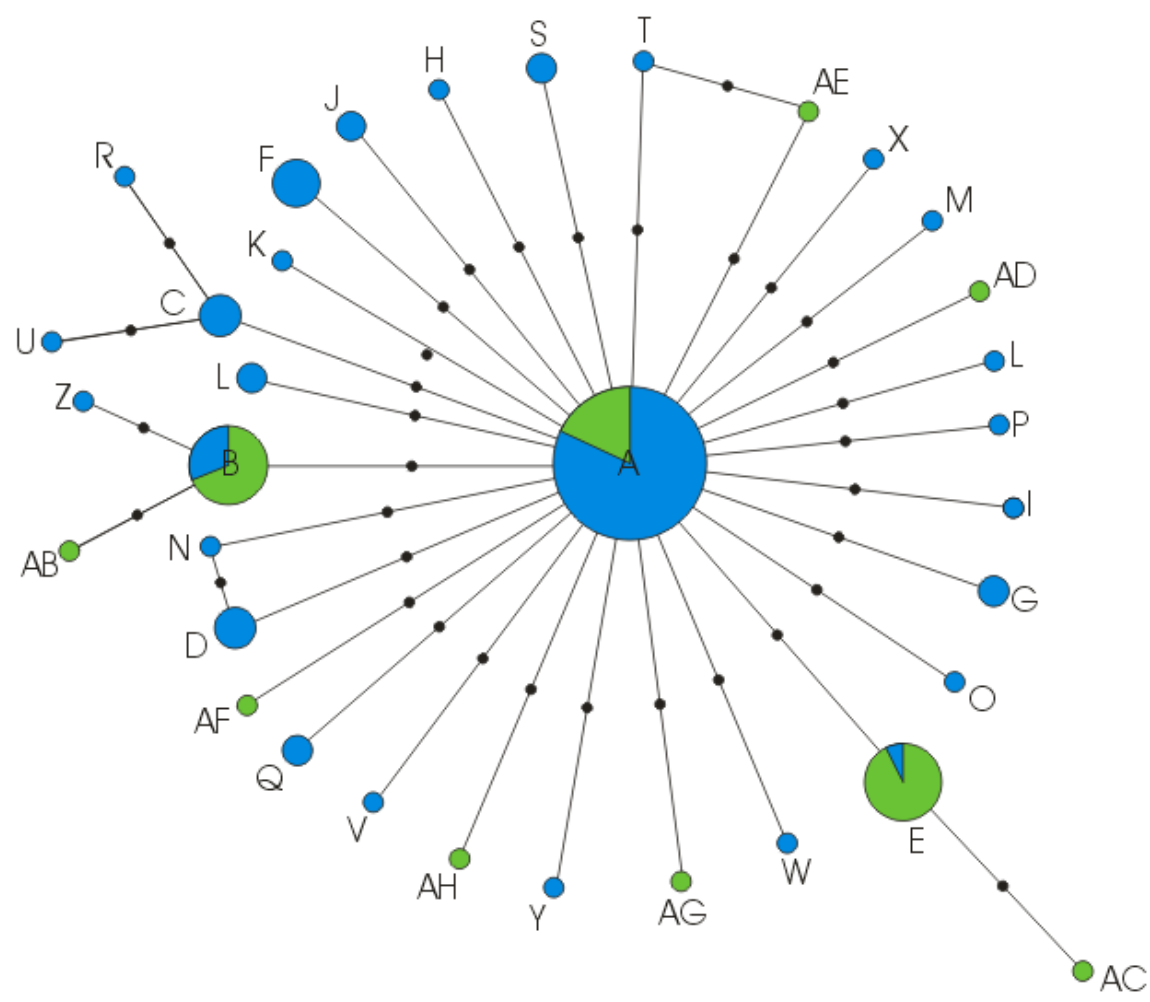

715 Figure 2. Median-joining network of Mya arenaria mtDNA haplotypes derived from COXI sequencing data. The circle area is proportional to the number of individuals characterised by a particular haplotype. The small black filled dots in the connecting lines represent mutational steps. Colours represent geographic location where haplotypes were found (blue - North America, green - Europe). Reticulations for unresolved links (e.g. T-A-AE and N-A-D) among haplotypes are also shown. Haplotype designations (A to $\mathrm{AH}$ ) are as used in Table 3.

722 


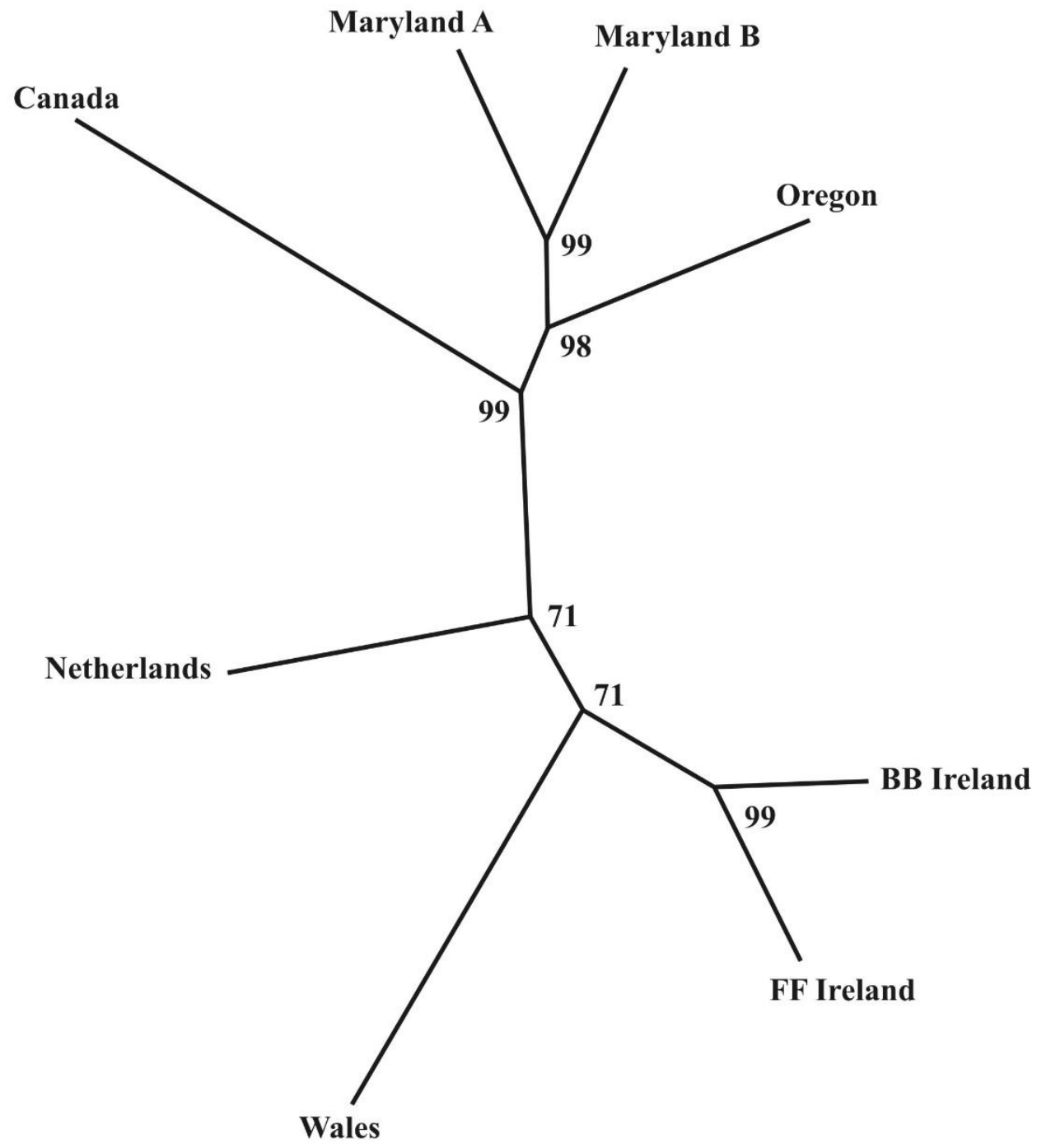

726

727 Figure 3. Unrooted neighbour-joining tree based on Nei et al. (1983) genetic distances

$728\left(\mathrm{D}_{\mathrm{A}}\right)$.Values on nodes represent percentage bootstrap support for groupings (out of 10,000 729 bootstraps).

730 

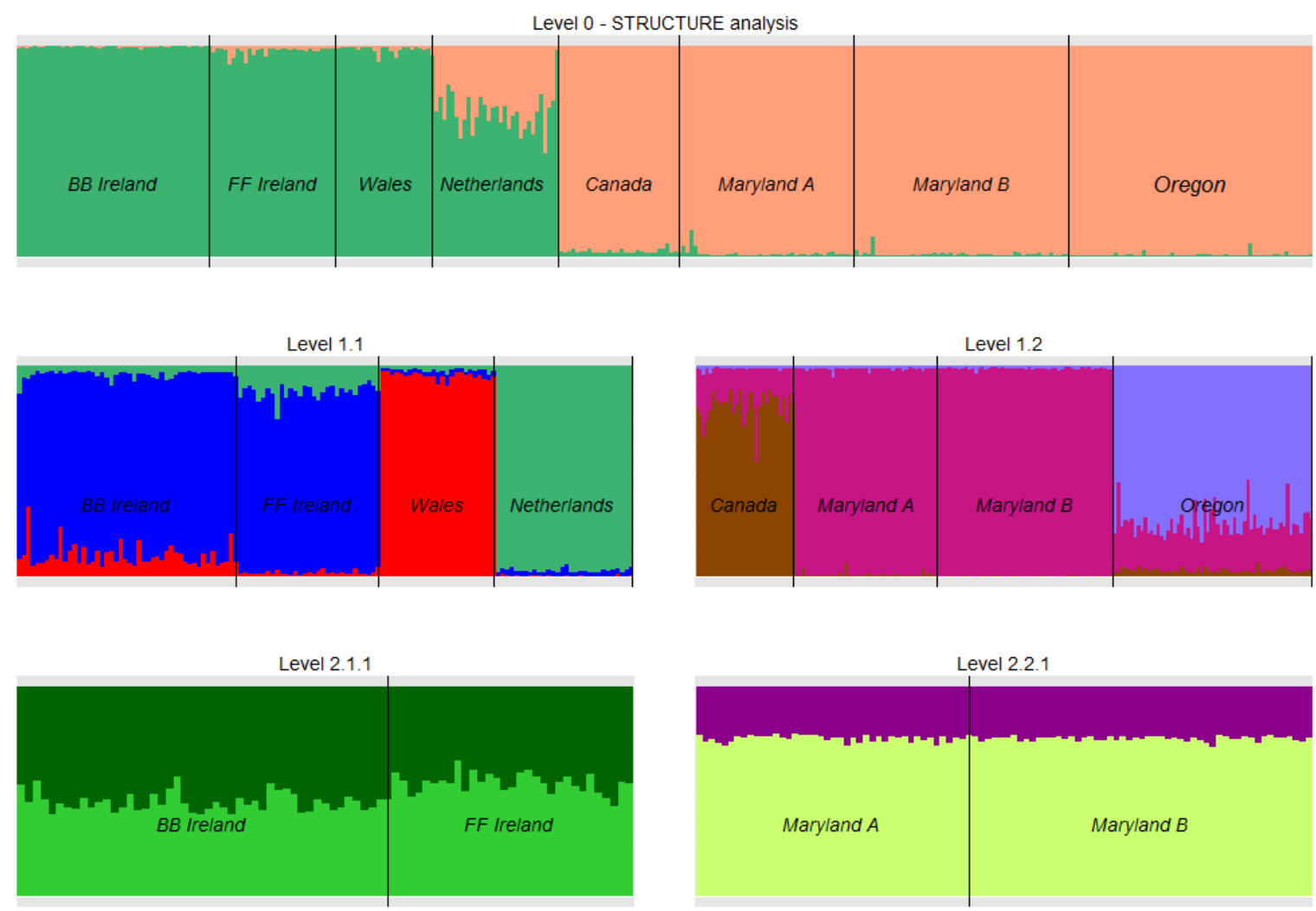

732 Figure 4. Estimated population structure from hierarchical STRUCTURE analyses for the full

733 data set (Level 0) and independent STRUCTURE runs subsequently carried out on samples

734 representing the major identifed groups (i.e. Hierarchical Levels 1 and 2 and respective

735 subgroups). In each instance (i.e. hierarchial level and group), each particular individual is

736 represented by a thin vertical line, which is divided into k coloured segments that represent

737 the individual's estimated membership fractions in k clusters. Black thicker lines separate

738 individuals from different samples. 
Table 1. Sampling locations and numbers of Mya arenaria specimens analysed in this study,

749 including summary statistics for ten microsatellite loci $(a=$ average number of alleles, $R s=$ 750 average allelic richness, $\mathrm{He}=$ expected heterozygosity, $\mathrm{Ho}=$ observed heterozygosity)

\begin{tabular}{|c|c|c|c|c|c|c|c|}
\hline Sample & (n) & Sample Area & Lat/Long & $a$ & $R s$ & $\mathrm{He}$ & Ho \\
\hline MLEB & 43 & $\begin{array}{l}\text { Eastern Bay, Maryland, eastern } \\
\text { USA, North America }\end{array}$ & $\begin{array}{l}38.886 \mathrm{~N} \\
76.340 \mathrm{~W}\end{array}$ & 22.2 & 11.14 & 0.901 & 0.798 \\
\hline MLMR & 53 & $\begin{array}{l}\text { Miles River, Maryland, eastern USA, } \\
\text { North America }\end{array}$ & $\begin{array}{l}38.816 \mathrm{~N} \\
76.237 \mathrm{~W}\end{array}$ & 24.8 & 11.15 & 0.901 & 0.831 \\
\hline $\mathrm{C}$ & 30 & $\begin{array}{l}\text { Prince Edward Island, Gulf of St. } \\
\text { Lawrence, eastern Canada }\end{array}$ & $\begin{array}{l}46.446 \mathrm{~N} \\
63.767 \mathrm{~W} \\
\end{array}$ & 14.6 & 9.01 & 0.844 & 0.747 \\
\hline $\mathrm{N}$ & 30 & $\begin{array}{l}\text { Hinderplaat, The Netherlands, } \\
\text { Europe }\end{array}$ & $\begin{array}{r}51.843 \mathrm{~N} \\
-04.009 \mathrm{~W}\end{array}$ & 1 & & 0.837 & 0.737 \\
\hline $\mathrm{BB}$ & 48 & Wexford, Ireland, Europe & $\begin{array}{l}52.251 \mathrm{~N} \\
06.763 \mathrm{~W}\end{array}$ & & 5.99 & 0.752 & 0.678 \\
\hline FF & 31 & Cork, Ireland, Europe & $\begin{array}{l}51.648 \mathrm{~N} \\
08.698 \mathrm{~W}\end{array}$ & 8.9 & 6.21 & 0.733 & 0.686 \\
\hline $\mathrm{W}$ & 25 & Menai Bridge, Wales, Europe & $\begin{array}{r}53.238 \mathrm{~N} \\
04.091 \mathrm{~W}\end{array}$ & 7.2 & 5.65 & 0.706 & 0.759 \\
\hline $\mathrm{O}$ & 60 & $\begin{array}{l}\text { Alsea Bay, Oregon, western USA, } \\
\text { North America }\end{array}$ & $\begin{array}{c}44.584 \mathrm{~N} \\
123.964 \mathrm{~W}\end{array}$ & 21.9 & 10.10 & 0.894 & 0.914 \\
\hline
\end{tabular}

751

752

753

754

755

756

757

758

759

760

761

762

763

764

765 
766

767

768

769

Table 2. Summary sample statistics derived from the mitochondrial COX1 sequencing data including: number of individuals $(\mathrm{N})$; number of haplotypes (nh); haplotype diversity $(h \pm s . d$.$) ;$ nucleotide diversity $\left(\pi 10^{-2}\right)$; and average number of nucleotide differences $(k)$. Bold font identifies samples collected in the current investigation.

\begin{tabular}{llccccc}
\hline Sample Area & Sample Code & N & nh & $h$ & $\pi$ & $k$ \\
\hline Maryland A & MLEB & 12 & 4 & $0.455 \pm 0.17$ & 0.094 & 0.500 \\
Maryland B & MLMR & 12 & 8 & $0.894 \pm 0.08$ & 0.244 & 1.303 \\
Eastern Bay, MD & EMD & 9 & 4 & $0.583 \pm 0.18$ & 0.167 & 0.889 \\
Miles River, MD & MMD & 15 & 4 & $0.371 \pm 0.15$ & 0.096 & 0.514 \\
Stony Brook, NY & NY & 15 & 5 & $0.476 \pm 0.16$ & 0.100 & 0.533 \\
Wareham, MA & WMA & 25 & 7 & $0.430 \pm 0.12$ & 0.119 & 0.633 \\
Mashpee, MA & MMA & 20 & 6 & $0.447 \pm 0.14$ & 0.110 & 0.600 \\
Barnstable, MA & BMA & 19 & 3 & $0.001 \pm 0.12$ & 0.039 & 0.211 \\
Quincy, MA & QMA & 22 & 3 & $0.177 \pm 0.11$ & 0.034 & 0.182 \\
Pembroke, ME & ME & 21 & 4 & $0.271 \pm 0.12$ & 0.071 & 0.381 \\
St. John, NB & NB & 11 & 4 & $0.491 \pm 0.03$ & 0.102 & 0.545 \\
Antigonish, NS & NS & 20 & 1 & & - & - \\
Canada & C & 16 & 2 & $0.125 \pm 0.11$ & 0.023 & 0.125 \\
Sylt, Germany & NSE & 15 & 3 & $0.530 \pm 0.14$ & 0.108 & 0.576 \\
Netherlands & N & 12 & 3 & $0.530 \pm 0.14$ & 0.108 & 0.576 \\
Bannow Bay, Irl & BB & 10 & 4 & $0.800 \pm 0.08$ & 0.226 & 1.200 \\
Flaxfort, Irl & FF & 10 & 3 & $0.711 \pm 0.09$ & 0.167 & 0.889 \\
Wales & W & 12 & 1 & - & - & - \\
Newport, OR & NEP & 20 & 5 & $0.574 \pm 0.74$ & 0.0013 & 0.668 \\
\hline Overall & & 296 & 34 & $0.422 \pm 0.04$ & 0.1071 & 0.521 \\
\hline
\end{tabular}

Table 3. MtDNA haplotype distribution of the analysed COXI region of $M$. arenaria. post Pleistocene spread of the species. Sampling sites abbreviations are given in Table 1 and 2. The shaded columns represent European sampling sites while the shaded rows represent haplotypes unique to European sites. Underlined sampling sites represent novel samples

781 collected in the current study. 'Nhap' = No. haplotypes per sample. Other samples are from 782 Genbank (see text for details). 


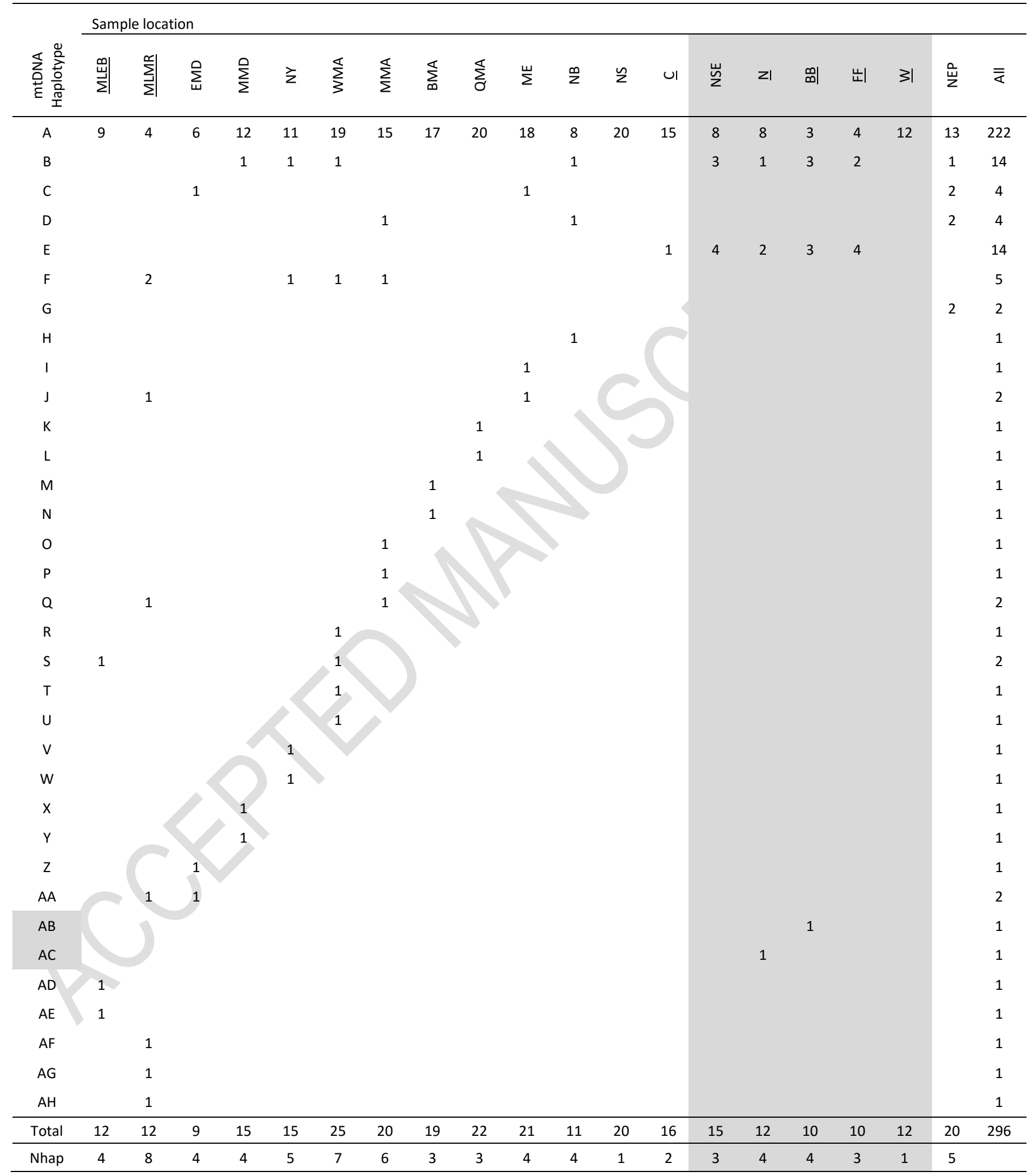


Table 4. Pairwise population $\Phi_{\text {st }}$ values for mtDNA sequence data, showing population pairwise $\Phi_{\text {st }}$ values below the diagonal and associated P values above. The values with a ' + ' sign above the diagonal are significant after standard Bonferroni correction. Site abbreviations are as given in Table 1 and 2.

\begin{tabular}{|c|c|c|c|c|c|c|c|c|c|c|c|c|c|c|c|c|c|c|c|}
\hline & MLEB & MLMR & EMD & MMD & NY & WMA & MMA & BMA & QMA & ME & NB & NS & $\mathrm{C}$ & NSE & $\mathrm{N}$ & BB & $\mathrm{FF}$ & W & NEP \\
\hline MLEB & & - & - & + & - & - & - & + & + & - & & + & + & - & - & + & + & - & + \\
\hline MLMR & 0.017 & & - & - & - & - & - & - & - & - & & + & - & - & - & + & + & - & - \\
\hline EMD & -0.008 & 0.008 & & - & - & - & - & - & - & 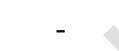 & & + & - & - & - & - & - & - & - \\
\hline MMD & 0.035 & 0.018 & -0.042 & & - & - & - & - & - & & 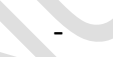 & - & - & - & - & + & + & - & - \\
\hline NY & 0.000 & -0.001 & -0.010 & -0.016 & & - & - & - & - & & - & + & - & - & - & + & + & - & - \\
\hline WMA & 0.023 & -0.017 & -0.020 & 0.001 & -0.015 & & - & - & & & - & - & - & - & + & + & + & - & - \\
\hline MMA & 0.003 & -0.003 & 0.013 & 0.015 & -0.013 & -0.001 & & - & & & - & - & - & + & + & + & + & - & - \\
\hline BMA & 0.049 & 0.014 & 0.047 & 0.033 & 0.007 & 0.001 & -0.008 & & 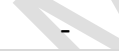 & - & - & - & - & + & + & + & + & - & - \\
\hline QMA & 0.061 & 0.021 & 0.060 & 0.040 & 0.012 & 0.005 & 0.003 & 0.001 & & - & - & - & - & + & + & + & + & - & + \\
\hline ME & 0.033 & 0.005 & 0.012 & 0.024 & 0.003 & -0.010 & 0.001 & -0.001 & 0.001 & & - & - & - & + & + & + & + & - & - \\
\hline NB & 0.013 & 0.000 & -0.024 & -0.028 & -0.023 & -0.010 & -0.018 & 0.006 & 0.028 & 0.008 & & + & - & - & - & + & + & - & - \\
\hline NS & 0.073 & 0.045 & 0.097 & 0.060 & 0.020 & 0.000 & 0.000 & 0.003 & -0.004 & -0.002 & 0.058 & & - & + & + & + & + & - & - \\
\hline$C$ & 0.043 & 0.014 & 0.047 & 0.032 & 0.003 & -0.006 & -0.008 & -0.003 & -0.003 & -0.007 & 0.021 & 0.014 & & - & - & + & + & - & - \\
\hline NSE & 0.061 & 0.078 & -0.008 & -0.021 & 0.022 & 0.043 & 0.071 & 0.128 & 0.144 & 0.098 & 0.000 & 0.208 & - & & - & - & - & - & - \\
\hline$N$ & 0.061 & 0.078 & 0.043 & 0.058 & 0.059 & 0.062 & 0.071 & 0.128 & 0.144 & 0.098 & 0.051 & 0.208 & 0.057 & 0.013 & & - & - & - & + \\
\hline BB & 0.146 & 0.202 & 0.094 & 0.128 & 0.166 & 0.193 & 0.214 & 0.293 & 0.319 & 0.259 & 0.132 & 0.375 & $0.258 ?$ & 0.001 & 0.038 & & - & + & + \\
\hline $\mathrm{FF}$ & 0.130 & 0.191 & 0.111 & 0.152 & 0.167 & 0.177 & 0.190 & 0.283 & 0.308 & 0.239 & 0.146 & 0.385 & 0.226 & 0.049 & -0.043 & -0.044 & & + & + \\
\hline W & 0.023 & 0.000 & 0.034 & 0.017 & -0.016 & -0.025 & -0.028 & -0.026 & -0.031 & -0.029 & 0.008 & 0.000 & -0.019 & 0.136 & 0.136 & 0.280 & 0.290 & & - \\
\hline NEP & 0.044 & 0.021 & -0.015 & 0.017 & 0.013 & -0.001 & 0.009 & 0.022 & 0.039 & 0.013 & -0.023 & 0.045 & 0.028 & 0.052 & 0.075 & 0.184 & 0.175 & 0.010 & \\
\hline
\end{tabular}


1 Table 5: $F_{\mathrm{ST}}$ estimates for ten microsatellite loci, after correction for the presence of null 2 alleles.

\begin{tabular}{llllllll}
\hline & MLEB & MLMR & C & N & BB & FF & W \\
\hline MLMR & $0.0017 *$ & & & & & & \\
C & 0.0381 & 0.0379 & & & & & \\
N & 0.0316 & 0.0377 & 0.0648 & & & & \\
BB & 0.0701 & 0.0742 & 0.0923 & 0.0513 & & & \\
FF & 0.0763 & 0.0771 & 0.0996 & 0.0549 & 0.0165 & & \\
W & 0.0910 & 0.0832 & 0.1131 & 0.0975 & 0.0909 & 0.1009 & \\
O & 0.0174 & 0.0182 & 0.0486 & 0.0355 & 0.0773 & 0.0816 & 0.0980
\end{tabular}

3 Pairwise $F_{\text {ST }}$ values are shown. ${ }^{*}$ The value is not statistically significantly different after standard Bonferroni 4 correction.

5 